\title{
Effects of Heat and Steam on the Mechanical Properties and Dimensional Stability of Thermo-hygromechanically- densified Sugar Maple Wood
}

\author{
Qilan $\mathrm{Fu}^{,}{ }^{\mathrm{a}}$ Alain Cloutier, ${ }^{\mathrm{a}, *}$ and Aziz Laghdir ${ }^{\mathrm{b}}$
}

\begin{abstract}
Effects of heat and steam were investigated relative to the mechanical properties and dimensional stability of thermo-hygromechanicallydensified sugar maple wood (Acer saccharum Marsh.). The densification process was performed at four temperatures $\left(180^{\circ} \mathrm{C}, 190^{\circ} \mathrm{C}, 200^{\circ} \mathrm{C}\right.$, and $210^{\circ} \mathrm{C}$ ) with and without steam. The hardness, bending strength, bending stiffness, and compression set recovery of the control and densified samples were determined. The effects of heat and steam on the density profile of the samples across thickness were also investigated. The results suggested that the effects of steam on the mechanical properties and dimensional stability of sugar maple wood were more important than that of heat's influence. Compared to the samples densified without steam, the samples densified with steam showed higher values for hardness, bending strength, bending stiffness, compression set, and density, but much lower compression set recovery when treatment temperature was below $200^{\circ} \mathrm{C}$. High temperature combined with steam contributed to decreased compression set recovery. The lowest compression set recovery was obtained after the first swelling/drying cycle for all of the treatments. A higher weight loss occurred at $210{ }^{\circ} \mathrm{C}$, which resulted in a noticeable decrease of wood density.
\end{abstract}

Keywords: Thermo-hygromechanical densification; Dimensional stability; Bending strength; Bending stiffness; Compression set recovery; Hardness; Density profile

Contact information: a: Centre de Recherche sur les Matériaux Renouvelables (Renewable Materials Research Center), Département des Sciences du Bois et de la Forêt (Department of Wood and Forest Science), Université Laval, Québec, QC, Canada, GIV 0A6; b: Research scientist, Service de Recherche et d'Expertise en Transformation des Produits Forestiers (Research and Expertise Service on Transformation of Forest Products), 25 Armand-Sinclair, Porte 5, Amqui, QC, Canada, G5J 1K3; *Corresponding author: alain.cloutier@sbf.ulaval.ca

\section{INTRODUCTION}

To be more competitive against other building materials, wood products must have desirable properties, such as mechanical strength, hardness, and dimensional stability, in addition to their environmental advantage. It is well known that the mechanical properties of wood increase with density. Therefore, any treatment resulting in an increase of wood density should result in higher quality products. Thermo-hygromechanical densification (THM) is an emerging modification treatment that involves the utilization of heat, steam, and pressure to densify wood (Navi and Girardet 2000). The main purpose of densification is to enhance wood density by reducing the cell lumen volume, hence to improve its mechanical performance and commercial value. In recent years, the use of THM densification to improve wood properties has generated much interest and a large amount 
of related studies have been published (Diouf et al. 2011; Rautkari et al. 2011; Fang et al. 2012a; Ahmed et al. 2013; Li et al. 2013; Gaff and Gašparík 2013; Laine et al. 2014; Fu et al. 2016).

Under the combined effects of heat, steam, and compression applied during the THM densification process, wood polymers are subjected to large deformations, with the exception of the crystalline part of cellulose (Navi and Heger 2004). Simultaneously, elastic strain energy is created and stored in amorphous and semi-crystalline cellulose and microfibrils. This is considered as the main explanation of the set recovery (Laine et al. 2013). Three fundamental mechanisms were proposed by Norimoto et al. (1993) to prevent set recovery: relaxation of internal stresses; formation of cross-linkages between matrix components; and isolation of the wood polymers from moisture and heat to avoid resoftening. The first two mechanisms most likely contribute to the improvement of the dimensional stability of THM-densified wood. Ito et al. (1998) proposed that semicrystalline cellulose is damaged and disturbed during high compressive deformation, allowing the relaxation of internal stresses. The hydrolysis of hemicelluloses occurring during the THM densification process also plays an important role in improving the dimensional stability of wood (Navi and Heger 2004). Hemicelluloses degrade at temperatures close to $200{ }^{\circ} \mathrm{C}$. They are the most sensitive polymers when exposed to heat and steam, due to their lower degree of polymerization and amorphous structure. The hydrolysis of amorphous cellulose has also been reported to lead to a higher crystallinity of cellulose in heat-treated wood (Silva et al. 2013; Xiao et al. 2014). Generally, a higher crystallinity of cellulose results in higher mechanical strength and dimensional stability. In particular, compression set recovery could be significantly reduced by increasing treatment temperature (Navi and Girardet 2000; Navi and Heger 2004; Welzbacher et al. 2008; Kutnar and Kamke 2012a). For example, Fang et al. (2012a) have found that recovery decreased dramatically when densification temperature exceeded $180{ }^{\circ} \mathrm{C}$. Almost no recovery was observed for veneers densified at $220^{\circ} \mathrm{C}$.

The mechanical properties of THM-densified wood can be increased or decreased depending on the treatment temperature. In the range of $150{ }^{\circ} \mathrm{C}$ to $180{ }^{\circ} \mathrm{C}$, the mechanical performance of THM-densified wood is reported to be significantly improved in comparison with untreated wood (Navi and Girardet 2000; Kutnar and Kamke 2012a; Fang et al. 2012a). In contrast, subjecting wood materials to high temperature results in a degradation of wood polymers, as first evidenced by weight loss (Repellin and Guyonnet 2005; Yildiz et al. 2005; Boonstra et al. 2007). Studies (Navi and Heger 2004; Fang et al. 2012b) have demonstrated that the hardness, bending strength, and bending stiffness decrease to some extent following the treatment above a given temperature. In addition, steam is also expected to have an influence on the mechanical properties and dimensional stability of THM-densified wood. From a theoretical point of view, steam is considered to soften the wood and cause a relaxation of the internal stresses during thermal treatments. Ito et al. (1998) and Dwianto et al. (1996) found that wood compressed in the presence of saturated steam at $180{ }^{\circ} \mathrm{C}$ to $200{ }^{\circ} \mathrm{C}$ shows a relaxation of stresses in the microfibrils and an increase of cellulose crystallinity. As is well known, the increase of cellulose crystallinity can contribute to the improvement of mechanical properties and dimensional stability. Nevertheless, few studies have been performed to specifically investigate the effects of steam during the THM densification process. Therefore, a closer investigation of its impact on the physical and mechanical behavior of densified wood is needed. 
The main objective of this study is to determine the effects of heat and steam applied during THM densification on the dimensional stability and mechanical performance of wood. This research further investigates the effects of steam on the density profile across sample thickness.

\section{EXPERIMENTAL}

\section{Materials}

Thin sawn strips of sugar maple (Acer saccharum March.) wood obtained from a hardwood flooring plant were used (Lauzon, Distinctive Hardwood Flooring Inc., Papineauville, Québec, Canada). Their average apparent density (at $20{ }^{\circ} \mathrm{C}$ and $65 \%$ relative humidity $(\mathrm{RH})$ ) was $734 \mathrm{~kg} / \mathrm{m}^{3}$ and their dimensions were $5.7 \mathrm{~mm}$ (radial) $\times 84.0 \mathrm{~mm}$ (tangential) $\times 695.0 \mathrm{~mm}$ (longitudinal). When they were received, the strips were stored in a conditioning room at $20{ }^{\circ} \mathrm{C}$ and $65 \% \mathrm{RH}$ until an equilibrium moisture content of approximately $12 \%$ was achieved. Nine groups of 8 strips were prepared: 8 groups densified at $180{ }^{\circ} \mathrm{C}, 190{ }^{\circ} \mathrm{C}, 200{ }^{\circ} \mathrm{C}$, and $210^{\circ} \mathrm{C}$, with and without steam, respectively, and one group of control samples.

\section{Methods}

Thermo-hygromechanical densification process

A steam injection press (Dieffenbacher, Alpharetta, USA) with dimensions of 862 $\mathrm{mm} \times 862 \mathrm{~mm}$ was used for the densification treatment (Fig. 1a, Fang et al. 2012a). Steam injection holes with a diameter of $1.5 \mathrm{~mm}$ were distributed uniformly at $32 \mathrm{~mm}$ intervals on both the upper and lower platens of the press (Fig. 1b). The specimens were placed on the lower platen for all treatments. To reduce wood surface carbonization and distribute the steam uniformly, both surfaces of the specimens were covered by a thin heat-resistant fabric permeable to steam made of Nomex ${ }^{\circledR} \amalg$ A manufactured by Dupont ${ }^{\mathrm{TM}}$ (Fang et al. $2012 \mathrm{~b}$ ). The two platens were preheated to the target temperature before treatment. Four temperatures were used: $180{ }^{\circ} \mathrm{C}, 190{ }^{\circ} \mathrm{C}, 200{ }^{\circ} \mathrm{C}$, and $210{ }^{\circ} \mathrm{C}$. The upper platen reached the specimens within $86 \mathrm{~s}$.
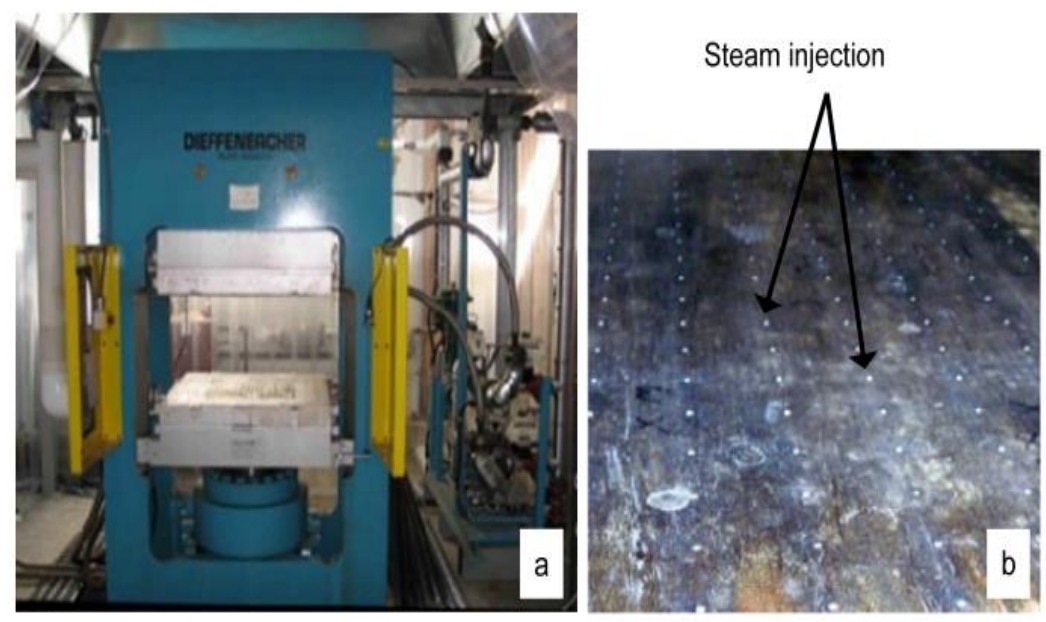

Fig. 1. Steam injection hot press used for THM densification treatments. a) $862 \mathrm{~mm} \times 862 \mathrm{~mm}$ hot press, b) press platen with steam injection holes 
The whole densification process could be divided into three steps: wood softening (duration of $400 \mathrm{~s}$ ); compression (duration of $1000 \mathrm{~s}$ ); and post-treatment (duration of 1500 s). Total treatment duration was approximately $3000 \mathrm{~s}$. Steam was continuously injected during the whole densification process at a maximum manometer pressure of $550 \mathrm{kPa}$ under an increasing mechanical manometer platen pressure up to $6 \mathrm{MPa}$ on the specimens. At the end of the treatment, steam injection was stopped and steam was purged through the holes in the platens. For densification without steam, the process parameters were kept the same but no steam was injected into the press. All of the treated specimens were then stored in a conditioning room at $20{ }^{\circ} \mathrm{C}$ and $65 \% \mathrm{RH}$ until their equilibrium moisture content was reached prior to their properties determination.

\section{Properties determination- Brinell hardness test}

Hardness is a relevant mechanical property to assess the suitability of a wood species for applications such as flooring and furniture manufacturing. The hardness of the specimens, before and after densification, was measured using a testing machine (MTSQTestTM/5, Eden Prairie, MN, USA) with a load cell of $10 \mathrm{kN}$. The measurements were performed according to EN 1534 (2000), with an indenter of $10 \mathrm{~mm}$ in diameter. The maximum load applied was $1000 \mathrm{~N}$, which was reached in $15 \mathrm{~s}$ and then maintained for 25 s. Eight replications were performed for each type of specimen for the determination of hardness, and the average value was used. The Brinell hardness of each specimen was calculated as follows,

$$
H=F /(\pi D h)
$$

where $H$ is Brinell hardness (MPa), $F$ is the maximum applied load $(\mathrm{N}), D$ is the diameter of the indenter (mm), and $h$ is the maximum depth of the indentation (mm). Once the load was applied to the specimen, the measurement of the depth of the indentation began, and its change over time was recorded by a computer. At the end of the measurement period, the maximum depth of the indentation was obtained and used in Eq. 1.

\section{Compression set and compression set recovery}

A compression set specifies the variation of thickness in the densified direction (radial). It was calculated according to Eq. 2,

$$
C_{\text {set }}(\%)=\left[\left(R_{0}-R_{\mathrm{A}}\right) / R_{0}\right] \times 100
$$

where $C_{\text {set }}$ is the compression set (\%), $R_{0}$ is the uncompressed thickness (mm) of samples, and $R_{\mathrm{A}}$ is the oven-dry thickness $(\mathrm{mm})$ of samples after densification.

Five cycles of swelling/drying were applied to evaluate the compression set recovery of wood. After densification, the specimens $(50 \mathrm{~mm}$ longitudinal $\times 50 \mathrm{~mm}$ tangential) were oven-dried to determine their oven-dry thickness before swelling. Ovendried samples were then soaked in water at room temperature for $24 \mathrm{~h}$ and oven-dried again for $24 \mathrm{~h}$. The thickness was measured in the oven-dry condition and after soaking in water. The compression set recovery was calculated using Eq. 3,

$$
\operatorname{CSR}(\%)=\left[\left(t_{\mathrm{s}}-t_{0}\right) /\left(t_{\mathrm{u}}-t_{0}\right)\right] \times 100
$$

where $C S R$ is the compression set recovery $(\%), t_{\mathrm{s}}$ is the oven-dry thickness $(\mathrm{mm})$ after swelling, $t_{0}$ is the oven-dry thickness $(\mathrm{mm})$ before swelling, and $t_{\mathrm{u}}$ is the initial uncompressed thickness $(5.7 \mathrm{~mm})$ at $T=20^{\circ} \mathrm{C}$ and $\mathrm{RH}=65 \%$. 


\section{Bending strength}

Specimens with dimensions of $130 \mathrm{~mm} \times 40 \mathrm{~mm}$ were prepared to perform the three-point static bending tests according to the ASTM D143-94 (2006) standard using a testing machine (MTS-QTestTM/5, Eden Prairie, MN, USA), to determine the bending strength and bending stiffness.

\section{Density profile measurement}

Specimens with dimensions of $50 \mathrm{~mm} \times 50 \mathrm{~mm}$ were used to measure the density profile across thickness before and after densification using an X-ray densitometer (Quintek Measurements Systems, model QDP-01X, Knoxville, TN, USA) at intervals of $0.04 \mathrm{~mm}$ through the thickness direction of the specimens.

\section{Statistical analysis}

An analysis of variance (ANOVA) was performed to investigate the effects of heat and steam on the mechanical properties of densified sugar maple wood using SAS 9.4 (SAS Institute Inc., Cary, NC, USA) at the significance level $\alpha=0.05$. Scheffe's, Duncan's and Tukey's test was conducted respectively for multiple comparisons between the average values obtained under different treatments.

\section{RESULTS AND DISCUSSION}

\section{Hardness}

The extent of change in hardness depended upon many factors. Low-density species usually exhibit a higher increase in hardness. The densification process parameters also impact wood density after the densification treatment (Kamke 2006; Fang et al. 2012a; Li et al. 2013). Fukuta et al. (2007) found that hardness did not increase proportionally with density. Table 1 presents the results obtained for hardness with and without steam injection. Table 2 presents the analysis of variance results of hardness versus temperature.

Table 1. Hardness of the Control and Specimens Densified under Different Conditions

\begin{tabular}{|c|c|c|c|c|}
\hline Treatments & $\begin{array}{c}\text { Hardness (MPa) } \\
(\mathrm{n}=8)\end{array}$ & $\begin{array}{c}\text { Scheffe's } \\
\text { Test }\end{array}$ & $\begin{array}{c}\text { Duncan's } \\
\text { Test }\end{array}$ & $\begin{array}{c}\text { Tukey's } \\
\text { Test }\end{array}$ \\
\hline Untreated & $30.7(2.2)$ & $\mathrm{c}$ & $\mathrm{c}$ & $\mathrm{c}$ \\
\hline $180^{\circ} \mathrm{C}$ Without Steam & $32.6(4.3)$ & $\mathrm{c}$ & $\mathrm{c}$ & $\mathrm{bc}$ \\
\hline $190^{\circ} \mathrm{C}$ Without Steam & $33.0(3.6)$ & $\mathrm{c}$ & $\mathrm{c}$ & $\mathrm{bc}$ \\
\hline $200^{\circ} \mathrm{C}$ Without Steam & $35.0(2.0)$ & $\mathrm{bc}$ & $\mathrm{bc}$ & $\mathrm{bc}$ \\
\hline $210^{\circ} \mathrm{C}$ Without Steam & $43.7(2.9)$ & $\mathrm{ab}$ & $\mathrm{a}$ & $\mathrm{a}$ \\
\hline $180^{\circ} \mathrm{C}$ With Steam & $44.2(2.4)$ & $\mathrm{a}$ & $\mathrm{a}$ & $\mathrm{a}$ \\
\hline $190^{\circ} \mathrm{C}$ With Steam & $44.6(3.0)$ & $\mathrm{a}$ & $\mathrm{a}$ & $\mathrm{a}$ \\
\hline $200^{\circ} \mathrm{C}$ With Steam & $43.3(7.5)$ & $\mathrm{ab}$ & $\mathrm{a}$ & $\mathrm{a}$ \\
\hline $210^{\circ} \mathrm{C}$ With Steam & $38.7(7.6)$ & $\mathrm{abc}$ & $\mathrm{b}$ & $\mathrm{ab}$ \\
\hline
\end{tabular}

Values in parenthesis are standard deviations; in each multiple-comparison test method, average values with the same letter indicate no significant difference at $\alpha=0.05$ 
Table 2. Analysis of Variance Results of Hardness versus Temperature

\begin{tabular}{|c|c|c|c|c|c|c|}
\hline Source & $\begin{array}{c}\text { Sum of } \\
\text { Squares }\end{array}$ & DF & $\begin{array}{c}\text { Mean } \\
\text { Square }\end{array}$ & $\begin{array}{c}\mathrm{F} \\
\text { Value }\end{array}$ & $p$ Value & Remarks \\
\hline $\begin{array}{c}\text { Temperature (Without } \\
\text { Steam) }\end{array}$ & 492.8 & 1 & 492.8 & 32.5 & $<0.0001$ & Significant \\
\hline $\begin{array}{c}\text { Temperature (With } \\
\text { Steam) }\end{array}$ & 125.8 & 1 & 125.8 & 4.0 & 0.0552 & \\
\hline
\end{tabular}

In the absence of steam, temperature had a significant effect on hardness ( $p<$ 0.0001). The hardness of samples densified without steam at $210{ }^{\circ} \mathrm{C}$ was significantly higher than that of the control samples. The hardness of samples densified with steam at the four temperatures considered was not statistically different, but it was significantly higher than that of the control samples. At $180{ }^{\circ} \mathrm{C}$ and $190{ }^{\circ} \mathrm{C}$, the hardness of the samples densified with steam was higher than that of the samples densified without steam. This demonstrated that steam had a positive effect to increase the hardness. When steam was applied, the effect of temperature on hardness was not significant $(p=0.0552)$.

\section{Bending Strength and Bending Stiffness}

The bending strength and bending stiffness of the control and densified samples at different temperatures $\left(180{ }^{\circ} \mathrm{C}, 190{ }^{\circ} \mathrm{C}, 200{ }^{\circ} \mathrm{C}\right.$, and $\left.210^{\circ} \mathrm{C}\right)$, with and without steam, are presented in Tables 3 and 5, respectively. Tables 4 and 6 presents the analysis of variance results of bending strength and bending stiffness versus temperature, respectively. Compared to the control samples, both the bending strength and bending stiffness increased after THM densification treatments. This increase in bending strength and bending stiffness might have been attributed to the increase in density after the densification treatments.

As shown in Table 3, the three multiple-comparison tests results revealed that after densification without steam, the bending strength became significantly higher than those of the control samples at $200{ }^{\circ} \mathrm{C}$ and $210{ }^{\circ} \mathrm{C}$. The treatment temperature also had a significant effect $(p<0.0001)$ on bending strength (Table 4$)$. At the same temperatures, the bending strength of the samples densified with steam were higher than those of the samples densified without steam, with the exception of the samples densified at $210{ }^{\circ} \mathrm{C}$. The steam injection resulted in further increases in bending strength, which were notably higher than those of the control and the samples densified without steam. However, the effect of temperature was not significant when steam was applied, as demonstrated in Table 4.

After densification without steam, the bending stiffness had a similar tendency to the bending strength, the bending stiffness became remarkably higher than those of the control samples at $200{ }^{\circ} \mathrm{C}$ and $210^{\circ} \mathrm{C}$. The temperature had a significant effect $(p<0.0001)$ on bending stiffness (Table 6). This tendency was similar to the bending strength. When steam was applied, the multiple-comparison result of the bending stiffness data with the Scheffe's test was different than the results of the Duncan's test and the Tukey's test. According to the result of the Scheffe's test, the bending stiffness of samples densified with steam at the four temperatures considered was not statistically different. However, the effect of temperature on the bending stiffness was significant $(p=0.0019)$ when steam was applied, as demonstrated in Table 6. This indicated that the Scheffe's test might be too conservative and not suitable to be applied to the bending stiffness data. Based on the results of the Duncan's test and the Tukey's test, the steam injection resulted in further 
increases in bending stiffness, which were notably higher than those of the control samples. At the same temperatures, the bending stiffness of the samples densified with steam were higher than those of the samples densified without steam.

Table 3. Bending Strength of the Control and Specimens Densified under Different Conditions

\begin{tabular}{|c|c|c|c|c|}
\hline Treatments & $\begin{array}{c}\text { Bending } \\
\text { Strength(MPa) } \\
\quad(n=8)\end{array}$ & $\begin{array}{c}\text { Scheffe's } \\
\text { Test }\end{array}$ & $\begin{array}{c}\text { Duncan's } \\
\text { Test }\end{array}$ & $\begin{array}{c}\text { Tukey's } \\
\text { Test }\end{array}$ \\
\hline Untreated & $148.3(5.4)$ & $d$ & $\mathrm{~d}$ & $\mathrm{C}$ \\
\hline $180^{\circ} \mathrm{C}$ Without Steam & $154.2(10.6)$ & d & $\mathrm{cd}$ & C \\
\hline $190{ }^{\circ} \mathrm{C}$ Without Steam & $161.4(17.5)$ & $\mathrm{cd}$ & $\mathrm{cd}$ & C \\
\hline $200^{\circ} \mathrm{C}$ Without Steam & $168.2(15.2)$ & bcd & C & bc \\
\hline $210^{\circ} \mathrm{C}$ Without Steam & $195.7(22.2)$ & $a b c$ & $a b$ & $a b$ \\
\hline $180^{\circ} \mathrm{C}$ With Steam & $214.1(19.2)$ & a & a & a \\
\hline $190{ }^{\circ} \mathrm{C}$ With Steam & $202.0(18.2)$ & $a b$ & $a b$ & a \\
\hline $200^{\circ} \mathrm{C}$ With Steam & $213.9(16.2)$ & a & a & $a$ \\
\hline $210{ }^{\circ} \mathrm{C}$ With Steam & $191.5(23.8)$ & $a b c$ & $b$ & $a b$ \\
\hline
\end{tabular}

Values in parenthesis are standard deviations; in each multiple-comparison test method, average values with the same letter indicate no significant difference at $\alpha=0.05$

Table 4. Analysis of Variance Results of Bending Strength versus Temperature

\begin{tabular}{|c|c|c|c|c|c|c|}
\hline Source & $\begin{array}{c}\text { Sum of } \\
\text { Squares }\end{array}$ & DF & $\begin{array}{c}\text { Mean } \\
\text { Square }\end{array}$ & $\begin{array}{c}\mathrm{F} \\
\text { Value }\end{array}$ & $p$ Value & Remarks \\
\hline $\begin{array}{c}\text { Temperature (Without } \\
\text { Steam) }\end{array}$ & 6880.7 & 1 & 6880.7 & 22.9 & $<0.0001$ & Significant \\
\hline $\begin{array}{c}\text { Temperature (With } \\
\text { Steam) }\end{array}$ & 1242.4 & 1 & 1242.4 & 3.0 & 0.0919 & \\
\hline
\end{tabular}

Table 5. Bending Stiffness of the Control and Specimens Densified under Different Conditions

\begin{tabular}{|c|c|c|c|c|}
\hline Treatments & $\begin{array}{c}\text { Bending Stiffness } \\
(\mathrm{GPa}) \\
(\mathrm{n}=8)\end{array}$ & $\begin{array}{c}\text { Scheffe's } \\
\text { Test }\end{array}$ & $\begin{array}{c}\text { Duncan's } \\
\text { Test }\end{array}$ & $\begin{array}{c}\text { Tukey's } \\
\text { Test }\end{array}$ \\
\hline Untreated & $8.0(0.3)$ & $\mathrm{C}$ & $\mathrm{e}$ & $\mathrm{d}$ \\
\hline $180^{\circ} \mathrm{C}$ Without Steam & $9.8(0.5)$ & $\mathrm{bc}$ & $\mathrm{d}$ & $\mathrm{cd}$ \\
\hline $190^{\circ} \mathrm{C}$ Without Steam & $10.9(1.3)$ & $\mathrm{bc}$ & $\mathrm{cd}$ & $\mathrm{c}$ \\
\hline $200^{\circ} \mathrm{C}$ Without Steam & $11.5(0.8)$ & $\mathrm{b}$ & $\mathrm{c}$ & $\mathrm{c}$ \\
\hline $210^{\circ} \mathrm{C}$ Without Steam & $14.8(1.9)$ & $\mathrm{a}$ & $\mathrm{b}$ & $\mathrm{b}$ \\
\hline $180^{\circ} \mathrm{C}$ With Steam & $15.0(2.1)$ & $\mathrm{a}$ & $\mathrm{b}$ & $\mathrm{b}$ \\
\hline $190^{\circ} \mathrm{C}$ With Steam & $15.5(1.5)$ & $\mathrm{a}$ & $\mathrm{b}$ & $\mathrm{ab}$ \\
\hline $200^{\circ} \mathrm{C}$ With Steam & $17.8(2.2)$ & $\mathrm{a}$ & $\mathrm{a}$ & $\mathrm{a}$ \\
\hline $210^{\circ} \mathrm{C}$ With Steam & $17.8(2.4)$ & $\mathrm{a}$ & $\mathrm{a}$ & $\mathrm{a}$ \\
\hline
\end{tabular}

Values in parenthesis are standard deviations; in each multiple-comparison test method, average values with the same letter indicate no significant difference at $\alpha=0.05$ 
Table 6. Analysis of Variance Results of Bending Stiffness versus Temperature

\begin{tabular}{|c|c|c|c|c|c|c|}
\hline Source & $\begin{array}{c}\text { Sum of } \\
\text { Squares }\end{array}$ & DF & $\begin{array}{c}\text { Mean } \\
\text { Square }\end{array}$ & $\begin{array}{c}\mathrm{F} \\
\text { Value }\end{array}$ & $p$ Value & Remarks \\
\hline $\begin{array}{c}\text { Temperature (Without } \\
\text { Steam) }\end{array}$ & 97.0 & 1 & 97.0 & 51.5 & $<0.0001$ & Significant \\
\hline $\begin{array}{c}\text { Temperature (With } \\
\text { Steam) }\end{array}$ & 47.3 & 1 & 47.3 & 11.6 & 0.0019 & Significant \\
\hline
\end{tabular}

In addition to temperature, other parameters, such as compression ratio and steam pressure, may also have impacted the bending strength and bending stiffness of densified samples. Fukuta et al. (2007) found that an increase in the compression ratio resulted in an increase of the bending modulus of rupture (MOR) and modulus of elasticity (MOE) of wood. Kutnar and Kamke (2012b) revealed that the MOE and MOR increased proportionally to the increase in density of the specimens compressed under saturated steam conditions, while the compression with superheated steam produced an increase in the bending MOE and MOR less than expected from the increase in density. The information in these works suggested that the bending strength and stiffness should be influenced by temperature and final density of densified samples.

\section{Compression Set Recovery}

Table 7 shows the CSR value of each swelling/drying cycle and the average value for each treatment. The smallest CSR was obtained after the first swelling/drying cycle for all of the treatments. The subsequent swelling/drying cycles caused higher CSR values than the first cycle. These observations were in accordance with the results obtained by Kutnar and Kamke (2012a). Furthermore, the compression set recovery was notably influenced by treatment temperature (Table 8). The CSR decreased with an increase in temperature. This tendency was particularly clear for the specimens densified with steam. The lower CSR values (3.7\% and 3.4\%) were obtained for specimens densified at $200{ }^{\circ} \mathrm{C}$ and $210{ }^{\circ} \mathrm{C}$ with steam, which suggested a stable compression set at higher temperatures. The higher densification temperature that resulted in lower CSR might have been due to the hydrolysis of the hemicelluloses. This resulted in a reduction of the hygroscopicity of wood and a decrease in the bonds between microfibrils and lignin, which can be broken and reformed, providing additional void space for the rearrangement of the microfibrils and for the release of the internal stress (Inoue et al. 1993; Navi and Heger 2004). As a result, the shape recovery effect was reduced and the dimensional stability improved.

In the absence of steam, the lowest densification temperature $\left(180{ }^{\circ} \mathrm{C}\right)$ resulted in the highest CSR. It was decreased dramatically when the densification temperature exceeded $200{ }^{\circ} \mathrm{C}$. In addition, the CSR values of the specimens treated at $190{ }^{\circ} \mathrm{C}$ and 200 ${ }^{\circ} \mathrm{C}$ without steam were not statistically different. Steam was considered to favor the set of compressive deformation. As shown in Table 7, at the same temperatures, the CSR values of samples densified with steam were remarkably smaller than those of the samples densified without steam. The steam treatment can increase the compressibility of wood and markedly reduce the buildup of internal stresses in the microfibrils (Dwianto et al. 1998; Ito et al. 1998; Esteves et al. 2006). Heger et al. (2004) proposed two mechanisms that allow the relaxation of stresses in the microfibrils: the weak bond between microfibrils and lignin, and the removing of microfibrils caused by the hemicellulose hydrolysis. The mechanism of the fixation of compressive deformation by high-temperature steam 
treatment could be attributed to the chain scission of hemicellulose and a slight cleavage of lignin (Dwianto et al. 1998) or the increase of cellulose crystallinity induced by the hydrolysis of amorphous cellulose (Silva et al. 2013; Xiao et al. 2014). Kutnar and Kamke (2012a) found that the influence of steam is more significant than heat on the dimensional stability of wood. In the current study, within the range of treatment conditions shown in Table 7, it was also observed that steam was more important than heat to reduce the compression set recovery effect.

Table 7. Compression Set Recovery of Specimens Densified under Different Conditions

\begin{tabular}{|c|c|c|c|c|c|c|c|c|c|}
\hline \multirow[t]{2}{*}{ Treatments } & \multicolumn{5}{|c|}{$\begin{array}{l}\text { Compression Set Recovery (\%) } \\
\qquad(\mathrm{n}=8)\end{array}$} & \multirow{2}{*}{$\begin{array}{c}\text { Mean } \\
\text { Value }(\%) \\
(n=5)\end{array}$} & \multirow{2}{*}{$\begin{array}{l}\text { Scheffe's } \\
\text { Test }\end{array}$} & \multirow{2}{*}{$\begin{array}{l}\text { Duncan's } \\
\text { Test }\end{array}$} & \multirow{2}{*}{$\begin{array}{l}\text { Tukey's } \\
\text { Test }\end{array}$} \\
\hline & R1 & $\mathrm{R} 2$ & R3 & $\mathrm{R} 4$ & R5 & & & & \\
\hline $\begin{array}{c}180^{\circ} \mathrm{C} \\
\text { Without } \\
\text { Steam }\end{array}$ & 53.9 & 60.0 & 64.6 & 55.4 & 53.9 & $57.6(4.7)$ & $a$ & $a$ & $a$ \\
\hline $\begin{array}{c}190^{\circ} \mathrm{C} \\
\text { Without } \\
\text { Steam }\end{array}$ & 39.6 & 47.5 & 49.5 & 47.5 & 50.5 & 46.9 (4.3) & b & $b$ & $b$ \\
\hline $\begin{array}{c}200^{\circ} \mathrm{C} \\
\text { Without } \\
\text { Steam }\end{array}$ & 37.5 & 45.2 & 50.0 & 48.1 & 49.0 & $46.0(5.1)$ & $b$ & $b$ & b \\
\hline $\begin{array}{c}210{ }^{\circ} \mathrm{C} \\
\text { Without } \\
\text { Steam }\end{array}$ & 17.0 & 22.3 & 23.4 & 21.8 & 23.4 & $21.6(2.7)$ & $\mathrm{cd}$ & $d$ & $d$ \\
\hline $\begin{array}{c}180{ }^{\circ} \mathrm{C} \text { With } \\
\text { Steam }\end{array}$ & 21.6 & 36.2 & 30.7 & 30.7 & 32.7 & $30.4(5.4)$ & C & C & C \\
\hline $\begin{array}{c}190{ }^{\circ} \mathrm{C} \text { With } \\
\text { Steam }\end{array}$ & 8.3 & 16.6 & 15.2 & 16.6 & 15.7 & 14.5 (3.5) & $d$ & e & $d$ \\
\hline $\begin{array}{l}200{ }^{\circ} \mathrm{C} \text { With } \\
\text { Steam }\end{array}$ & 1.8 & 5.3 & 4.4 & 3.6 & 3.6 & $3.7(1.3)$ & e & $f$ & e \\
\hline $\begin{array}{l}210{ }^{\circ} \mathrm{C} \text { With } \\
\text { Steam }\end{array}$ & 1.4 & 4.1 & 4.5 & 3.6 & 3.2 & $3.4(1.2)$ & e & $f$ & e \\
\hline
\end{tabular}

Values in parenthesis are standard deviations; in each multiple-comparison test method, average values with the same letter indicate no significant difference at $\alpha=0.05$

Table 8. Analysis of Variance Results of Bending Stiffness versus Temperature

\begin{tabular}{|c|c|c|c|c|c|c|}
\hline Source & $\begin{array}{c}\text { Sum of } \\
\text { Squares }\end{array}$ & DF & $\begin{array}{c}\text { Mean } \\
\text { Square }\end{array}$ & $\begin{array}{c}\mathrm{F} \\
\text { Value }\end{array}$ & $p$ Value & Remarks \\
\hline $\begin{array}{c}\text { Temperature (Without } \\
\text { Steam) }\end{array}$ & 2106.8 & 1 & 2106.8 & 78.0 & $<0.0001$ & Significant \\
\hline $\begin{array}{c}\text { Temperature (With } \\
\text { Steam) }\end{array}$ & 2964.8 & 1 & 2964.8 & 66.6 & $<0.0001$ & Significant \\
\hline
\end{tabular}

The thickness variation of specimens during the swelling/drying cyclic recovery test is presented in Fig. 2. Different densification treatments resulted in different initial oven-dry thicknesses (values at D0). The smaller the initial oven-dry thickness, the higher the compression set, because all of the samples had the same initial uncompressed thickness (value at 1). During the first water swelling (from D0 to W1), the thickness increased substantially, particularly for the samples treated at low temperature without steam. Fang et al. (2012a) obtained similar results for THM-densified aspen and hybrid 
poplar wood. They found that the samples densified at high temperatures undergo smaller swelling compared to samples treated at low temperatures. Bonigut et al. (2014) suggested that it might be explained by the reduction of free hydroxyl groups in the hemicellulose resulting from its hydrolysis. Meanwhile, the degradation of hemicellulose can result in the generation of hydrophobic substances such as furan-based polymers (furfural and 5hydroxymethylfurfural) (Werner et al. 2014). del Menezzi et al. (2009) demonstrated that the presence of hydrophobic substances has a more important impact on the degree of thickness swelling than the temperature. In addition, densification at higher temperatures with steam results in a larger compression set, and results in a reduction of the porosity. Lastly, the quantity of accessible cavities used to store free water notably reduced.

After the first swelling/drying cycle, compared to the values at D0 and D1, it was observed that the thickness increased for all of the treatments. This increase in thickness might have been due to irreversible swelling. Both reversible and irreversible swelling occurred when the wood samples were subsequently immersed in water. The reversible swelling is caused by wood's hygroscopic nature, and the irreversible swelling is due to the compression set recovery (Fang et al. 2012a). However, Ohlmeyer and Paul (2010) suggested that the irreversible swelling may be induced by mechanical failure of the covalent bonds between hemicellulose and lignin when the swelling stress exceeds the bond bridges strength. In particular, not only in a water-saturated condition but also in an oven-dry condition, the thickness of the samples became almost stable for all of the treatments after the first swelling/drying cycle. This suggested that the irreversible swelling mainly occurred during the first swelling/drying cycle.

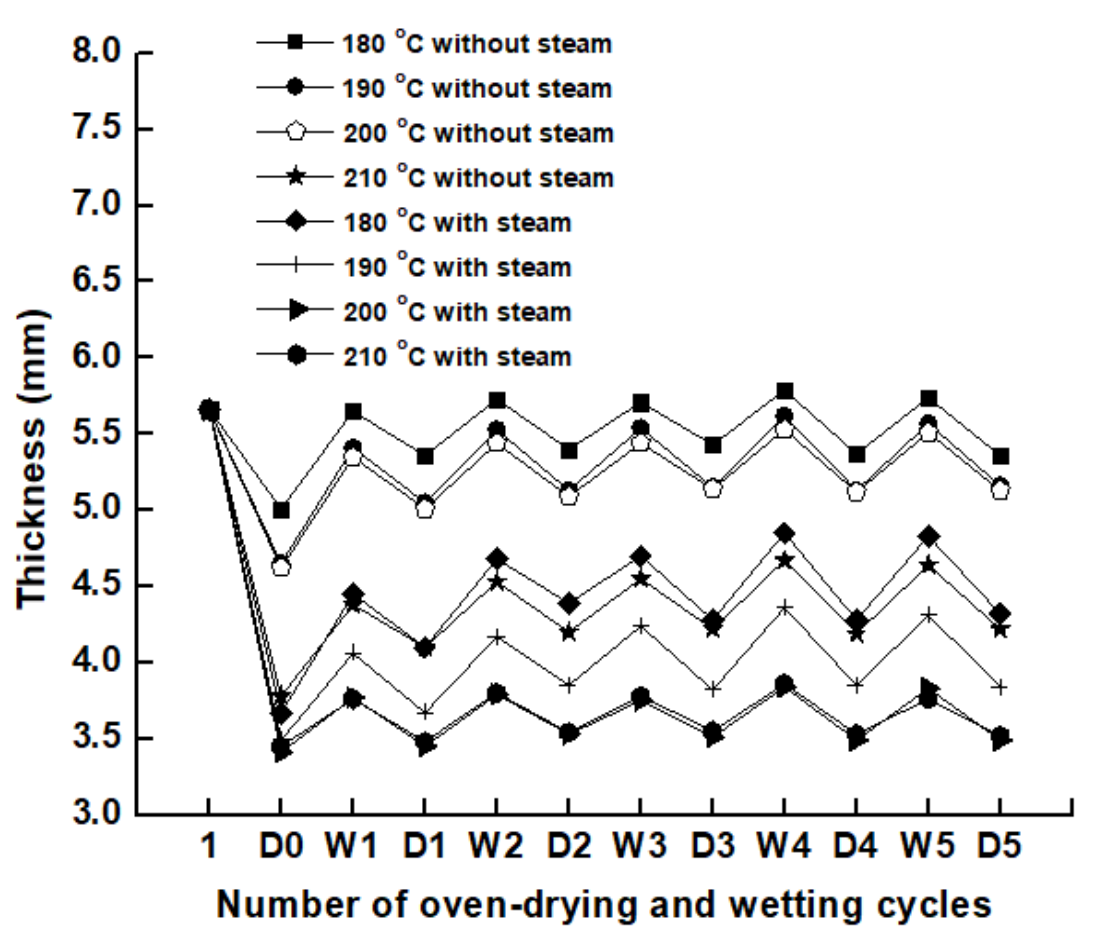

Fig. 2. Thickness variation due to swelling following water soaking and oven-drying of sugar maple wood densified under different conditions; " $D$ ", " $w$ " shows oven-drying and swelling following water soaking, respectively, "1" shows the initial thickness before treatment 


\section{Density Profiles}

Figure 3 presents the typical density profiles of the control samples and the samples densified at different temperatures $\left(180^{\circ} \mathrm{C}, 190^{\circ} \mathrm{C}, 200^{\circ} \mathrm{C}\right.$, and $\left.210{ }^{\circ} \mathrm{C}\right)$, with and without steam. As shown in Fig. 3, the density of the control sample was almost constant throughout the thickness, with the exception of the lower density values observed on both surfaces. The impact of steam on the density profile was evaluated by a comparison of Figs. 3A and 3B.

In the absence of steam (Fig. 3A), different densification temperatures resulted in different density profiles. These differences were observed via comparison of their average density and thickness values. The average density increased with increased temperature, with a maximum average density obtained at $210{ }^{\circ} \mathrm{C}$. In contrast, the thickness after densification decreased with increased temperature, especially when the temperature exceeded $200{ }^{\circ} \mathrm{C}$. Within the range of temperatures considered in this study, wood density increased with increased temperature. In addition, the samples densified without steam showed a higher density in the core than at the surface, this tendency was more significant for the samples densified at lower temperatures $\left(180^{\circ} \mathrm{C}\right.$ and $\left.190{ }^{\circ} \mathrm{C}\right)$. This might have been caused by the large spring back after the press opening. As presented in Table 7, the samples densified without steam showed higher compression set recovery than those densified with steam. The samples densified at $180{ }^{\circ} \mathrm{C}$ without steam showed the largest spring back, which could result in a much higher density in the core than at the surface.
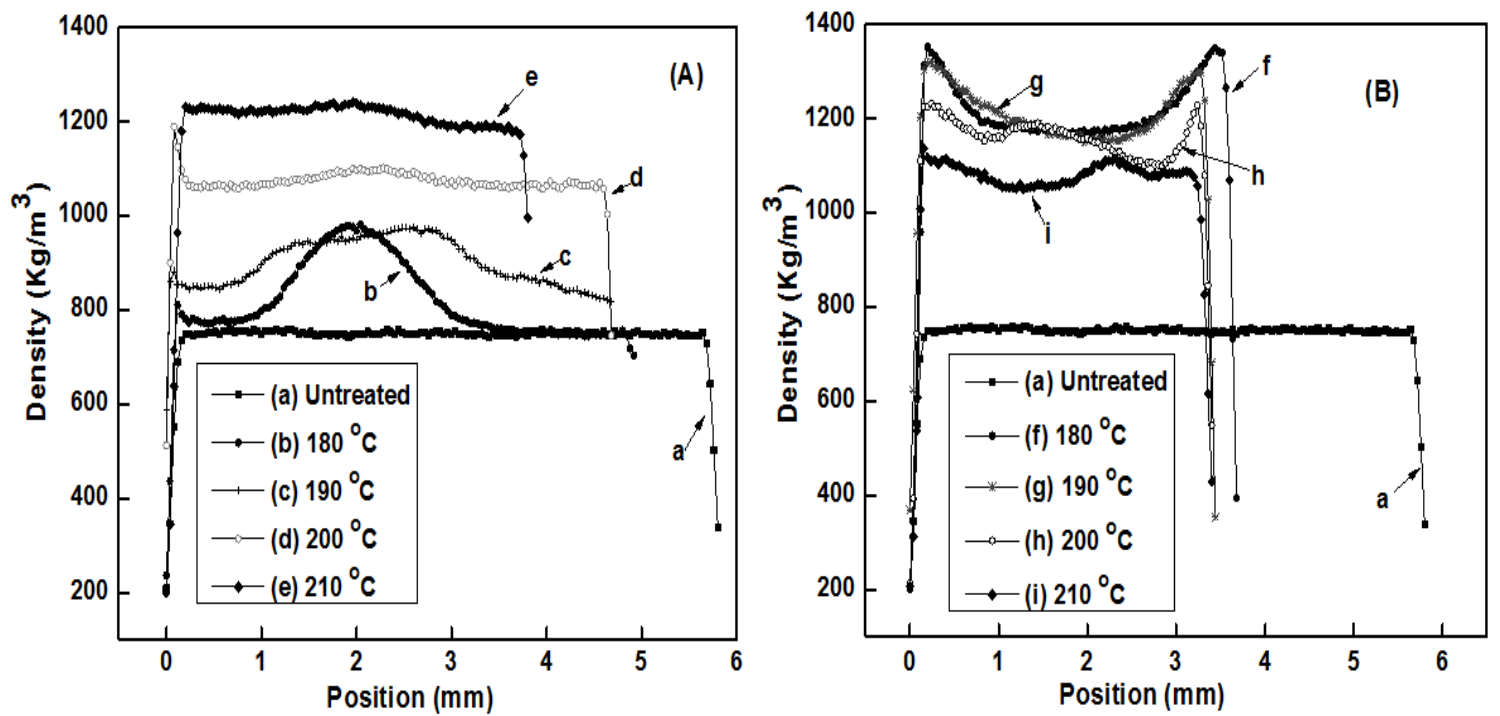

Fig. 3. Effect of densification temperature and steam on density profile; (A) Densified without steam; (B) Densified with steam

The density profiles shown in Fig. 3B demonstrated that the use of steam in the densification process had an important influence on the compression set of densified wood. Under the same temperatures and mechanical pressure, the samples densified with steam reached a higher compression set than the samples densified without steam. As shown in Fig. 3B, the average density of THM-densified samples dramatically increased compared to the control sample. The density was more homogeneous in the core of the samples treated at the different temperatures. Also, a higher density at the surface than in the core 
was found for most treatment temperatures when steam was used. This might have been due to the higher compression set obtained when steam was used, which led to the higher surface density. Moreover, steam injection also resulted in heat transfer by vapor convection due to a steeper vapor pressure gradient from the surface to the core. This led to a quick temperature rise in the core. As a result, the heat distribution across the transverse direction was likely more homogeneous for samples densified with steam. In addition, a higher weight loss occurred at $210^{\circ} \mathrm{C}$, which resulted in an obvious decrease of the average wood density, which might be induced by advanced degradation of the matrix (lignin and hemicelluloses) (Fang et al. 2012b).

\section{CONCLUSIONS}

1. The effects of steam on the mechanical properties and dimensional stability of sugar maple wood were more important than that of heat's influence. Compared to the samples densified without steam, samples densified with steam showed a higher hardness, bending strength, bending stiffness, and compression set, but much lower compression set recovery and higher density when the treatment temperature was below $200{ }^{\circ} \mathrm{C}$.

2. Samples densified at $210{ }^{\circ} \mathrm{C}$ with steam exhibited relatively lower hardness, lower bending strength, and lower density compared to the samples treated at the same temperature without steam. Advanced degradation of wood polymers occurred when steam was used at temperatures higher than $200{ }^{\circ} \mathrm{C}$. This resulted in a decrease of mechanical strength and density. Steam favored the advanced degradation of wood polymers, especially at the highest temperature $\left(210^{\circ} \mathrm{C}\right)$.

3. High temperature and steam contributed to set the compressive deformation. Densification at higher temperatures with steam resulted in a larger compression set. The smallest set recovery was obtained after the first swelling/drying cycle for all of the treatments. Both reversible and irreversible swelling occurred when the wood samples were subsequently soaked in water. The irreversible swelling mainly occurred during the first swelling/drying cycle.

4. Samples densified without steam showed a higher core density, and their average density increased with temperature. When steam was used in the densification process, the core density of the samples was more homogeneous at the different temperatures considered. Moreover, a higher density at the surface than in the core was also observed for these samples.

\section{ACKNOWLEDGEMENTS}

The authors thank Mr. David Lagueux for technical assistance with the densification process. The authors are grateful to the Natural Sciences and Research Council of Canada (NSERC) for funding this research under Discovery Grant No. 121954-2012. 


\section{REFERENCES CITED}

Ahmed, S. A., Morén, T., Hagman, O., Cloutier, A., Fang, C. H., and Elustondo, D. (2013). "Anatomical properties and process parameters affecting blister/blow formation in densified European aspen and downy birch sapwood boards by thermohygro-mechanical compression," Journal of Materials Science 48(24), 8571-8579. DOI: $10.1007 / \mathrm{s} 10853-013-7679-9$

ASTM D143-94 (2006). "Standard test methods for small clear specimens of timber," ASTM International, West Conshohocken, PA, USA.

Bonigut, J., Krug, D., and Stuckenberg, P. (2014). "Dimensional stability and irreversible thickness swell of thermally treated oriented strandboards (OSB)," European Journal of Wood and Wood Products 72(5), 593-599. DOI: 10.1007/s00107-014-0820-x

Boonstra, M. J., Van Acker, J., Tjeerdsma, B. F., and Kegel, E. V. (2007). "Strength properties of thermally modified softwoods and its relation to polymeric structural wood constituents," Annals of Forest Science 64(7), 679-690. DOI: 10.1051/forest:2007048

del Menezzi, C. H. S., Tomaselli, I., Okino, E. Y. A., Teixeira, D. E., and Santana, M. A. E. (2009). "Thermal modification of consolidated oriented strandboards: Effects on dimensional stability, mechanical properties, chemical composition and surface color," European Journal of Wood and Wood Products 67(4), 383-396. DOI: 10.1007/s00107-009-0332-2

Diouf, P. N., Stevanovic, T., Cloutier, A., Fang, C. H., Blanchet, P., Koubaa, A., and Mariotti, N. (2011). "Effects of thermo-hygro-mechanical densification on the surface characteristics of trembling aspen and hybrid poplar wood veneers," Applied Surface Science 257(8), 3558-3564. DOI: 10.1016/j.apsusc.2010.11.074

Dwianto, W., Tanaka, F., Inoue, M., and Norimoto, M. (1996). "Crystallinity changes of wood by heat or steam treatment," Wood Research: Bulletin of the Wood Research Institute Kyoto University 83, 47-49.

Dwianto, W., Morooka, T., and Norimoto, M. (1998). "The compressive stress relaxation of albizia (Paraserianthes falcata Becker) wood during heat treatment," Journal of the Japan Wood Research Society 44(6), 403-409.

EN 1534 (2000). "Wood and parquet flooring. Determination of resistance to indentation (Brinell)," European Committee for Standardization, Brussels, Belgium.

Esteves, B., Domingos, I., and Pereira, H. (2006). "Variation of dimensional stability and durability of eucalypt wood by heat treatment," in: Proceedings of Ecowood 2006, $2^{\text {nd }}$ International Conference on Environmentally-Compatible Forest Products. Fernado. Pessoa University. Oporto. Portugal. Pp.185-194.

Fang, C. H., Mariotti, N., Cloutier, A., Koubaa, A., and Blanchet, P. (2012a). "Densification of wood veneers by compression combined with heat and steam," European Journal of Wood and Wood Products 70(1-3), 155-163. DOI: 10.1007/s00107-011-0524-4

Fang, C. H., Blanchet, P., Cloutier, A., and Barbuta, C. (2012b). "Engineered wood flooring with a densified surface layer for heavy duty use," BioResources 7(4), 58435854. DOI: 10.15376/biores.7.4.5843-5854 
Fukuta, S., Takasu, Y., Sasaki, Y., and Hirashima, Y. (2007). "Compressive deformation process of Japanese cedar (Cryptomeria japonica)," Wood and Fiber Science: Journal of the Society of Wood Science and Technology 39(4), 548-555.

$\mathrm{Fu}$, Q., Cloutier, A., and Laghdir, A. (2016). "Optimization of the thermohygromechanical (THM) process for sugar maple wood densification," BioResources 11(4), 8844-8859. DOI: 10.15376/biores.11.4.8844-8859

Gaff, M., and Gašparík, M. (2013). "Shrinkage and stability of thermo-mechanically modified aspen wood," BioResources 8(1), 1136-1146. DOI:

10.15376/biores.8.1.1136-1146

Heger, F., Groux, M., Girardet, F., Welzbacher, C., Rapp, A. O., and Navi, P. (2004). "Mechanical and durability performance of THM-densified wood," in: Final Workshop Cost Action E22: Environmental Optimization of Wood Protection, Lisbon, Portugal.

Inoue, M., Norimoto, M., Tanahashi, M., and Rowell, R. M. (1993). "Steam or heat fixation of compressed wood," Wood and Fiber Science: Journal of the Society of Wood Science and Technology 25(3), 224-235.

Ito, Y., Tanahashi, M., Shigematsu, M., and Shinoda, Y. (1998). "Compressive-molding of wood by high-pressure steam-treatment: Part 2. Mechanism of permanent fixation," Holzforschung 52(2), 217-221. DOI: 10.1515/hfsg.1998.52.2.217

Kamke, F. A. (2006). "Densified radiata pine for structural composites," Maderas. Ciencia y Tecnologia 8(2), 83-92. DOI: 10.4067/S0718-221X2006000200002

Kutnar, A., and Kamke, F. A. (2012a). "Influence of temperature and steam environment on set recovery of compressive deformation of wood," Wood Science and Technology 46(5), 953-964. DOI: 10.1007/s00226-011-0456-5

Kutnar, A., and Kamke, F. A. (2012b). "Compression of wood under saturated steam, superheated steam, and transient conditions at $150^{\circ} \mathrm{C}, 160^{\circ} \mathrm{C}$ and $170{ }^{\circ} \mathrm{C}$," Wood Science and Technology 46(1-3), 73-88. DOI: 10.1007/s00226-010-0380-0

Laine, K., Belt, T., Rautkari, L., Ramsay, J., Hill, C. A., and Hughes, M. (2013). "Measuring the thickness swelling and set-recovery of densified and thermally modified Scots pine solid wood," Journal of Materials Science 48(24), 8530-8538. DOI: $10.1007 / \mathrm{s} 10853-013-7671-4$

Laine, K., Segerholm, K., Wålinder, M., Rautkari, L., Ormondroyd, G., Hughes, M., and Jones, D. (2014). "Micromorphological studies of surface densified wood," Journal of Material Science 49(5), 2027-2034. DOI: 10.1007/s10853-013-7980-8

Li, L., Gong, M., Yuan, N., and Li, D. (2013). “An optimal thermo-hydro-mechanical densification (THM) process for densifying balsam fir wood," BioResources 8(3), 3967-3981. DOI: 10.15376/biores.8.3.3967-3981

Navi, P., and Heger, F. (2004). "Combined densification and thermo-hydromechanical processing of wood," MRS Bulletin 29(5), 332-336. DOI: 10.1557/mrs2004.100

Navi, P., and Girardet, F. (2000). "Effects of thermo-hydro-mechanical treatment on the structure and properties of wood," Holzforschung 54(3), 287-293

DOI: $10.1515 /$ HF. 2000.048

Norimoto, M., Ota, C., Akitsu, H., and Yamada, T. (1993). "Permanent fixation of bending deformation in wood by heat treatment," Wood Research: Bulletin of the Wood Research Institute of Kyoto University 79, 23-33. 
Ohlmeyer, M., and Paul, W. (2010). "Optimierung der Eigenschaften von

Holzwerkstoffen mit Hilfe von thermischen Modifizierungsme-thoden [Optimization of the properties of wood materials by means of thermal modification methods] (Work Report No. 2010/2)," Institute of Wood Technology and Wood Biology, University of Hamburg, Hamburg, Germany.

Rautkari, L., Kamke, F. A., and Hughes, M. (2011). "Density profile relation to hardness of viscoelastic thermal compressed (VTC) wood composite," Wood Science and Technology 45(4), 693-705. DOI: 10.1007/s00226-010-0400-0

Repellin, V., and Guyonnet, R. (2005). "Evaluation of heat-treated wood swelling by differential scanning calorimetry in relation to chemical composition," Holzforschung 59(1), 28-34. DOI: 10.1515/HF.2004.131

Silva, M. R. D., Machado, G. D. O., Brito, J. O., and Calil Jr., C. (2013). "Strength and stiffness of thermally rectified eucalyptus wood under compression," Materials Research 16(5), 1077-1083.

Welzbacher, C. R., Wehsener, J., Rapp, A. O., and Haller, P. (2008). "Thermomechanical densification combined with thermal modification of Norway spruce (Picea abies Karst) in industrial scale-Dimensional stability and durability aspects," Holz als Roh-und Werkstoff 66(1), 39-49. DOI: 10.1007/s00107-007-0198-0

Werner, K., Pommer, L., and Broström, M. (2014). "Thermal decomposition of hemicelluloses," Journal of Analytical and Applied Pyrolysis 110, 130-137. DOI: 10.1016/j.jaap.2014.08.013

Xiao, L. P., Lin, Z., Peng, W. X., Yuan, T. Q., Xu, F., Li, N. C., Tao, Q. S., Xiang, H., and Sun, R. C. (2014). "Unraveling the structural characteristics of lignin in hydrothermal pretreated fibers and manufactured binderless boards from Eucalyptus grandis," Sustainable Chemical Processes 2(1), 9-21. DOI: 10.1186/2043-7129-2-9

Yildiz, U. C., Yildiz, S., and Gezer, E. D. (2005). "Mechanical and chemical behavior of beech wood modified by heat," Wood and Fiber Science 37(3), 456-461.

Article submitted: April 19, 2017; Peer review completed: August 12, 2017; Revised version received and accepted: October 16, 2017; Published: October 19, 2017.

DOI: $10.15376 /$ biores.12.4.9212-9226 